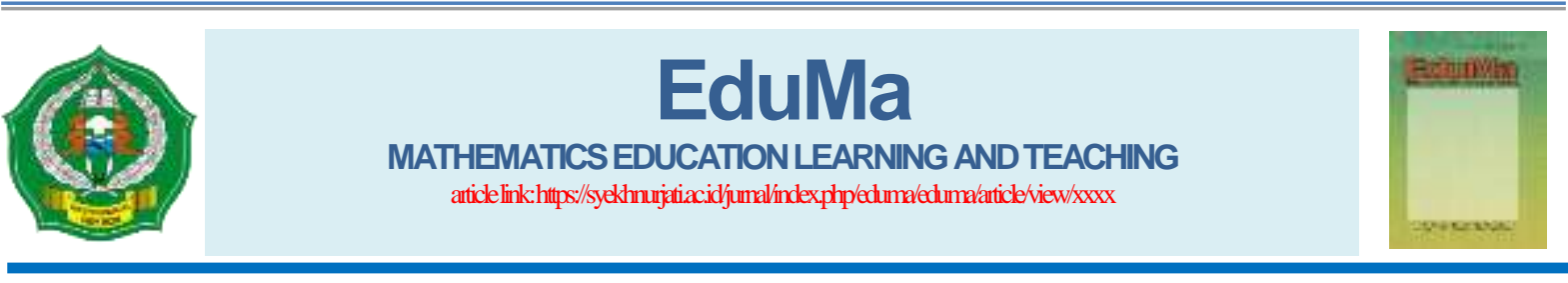

\title{
The Effect of Algebra Finger- Based Brain Gym Method to Improve Student Learning Outcomes
}

\author{
Komarudin ${ }^{1 *}$, Novi Rosmawati ${ }^{2}$, Suherman ${ }^{3}$, Bambang Sri Anggoro ${ }^{4}$ \\ 1,3,4 Universitas Islam Negeri Raden Intan, Lampung, 35131, Indonesia \\ ${ }^{2}$ MTs Al Hidayat Gerning, Lampung, 35363, Indonesia
}

*Corresponding author: JalanLetkol Endro Suratmin No.1 Sukarame, Bandar Lampung, Lampung, 35131, Indonesia. e-mail addresses: komarudin@radenintan.ac.id

\section{article info}

How to cite this article:

Komarudin, K., Rosmawati, N., \& Anggoro, B. S. (2019). The Effect of Algebra Finger-Based Brain Gym Method to Improved Studen Learning Outcomes. Eduma: Mathematics Education Learning And Teaching, 8(1), 80 - 88. doi:http://dx.doi.org/10.24235/eduma.v\%vi\%i.4202

Article history:

Received: 04 29, 2019

Accepted: 12 12, 2019

Published: 12 31, 2019

Copyright (C) 2019 by author (s) and EduMa: Mathematics Education Learning and Teaching under the Creative Commons Attribution-ShareAlike 4.0 International License.

\section{Abstrakt}

The Effect of Algebra Finger-Based Brain Gym Method to Improved Studen Learning Outcomes. This study aims to look at the effect of algebraic finger-based brain gym methods on improving student learning outcomes. This study uses grade VII students MTs. Al-Hidayat Gerning consisting of 4 (four) classes as population, then by cluster random sampling technique obtained class VII A and VII B as research samples. This study uses a quasi-experimental method, the independent variable is the algebraic finger-based brain gym method, and the dependent variable is the increase in learning outcomes. Data collection using test techniques, with the research instrument in the form of a matter of description which amounted to 6 questions that have been tested for validity, reliability, level of difficulty, and different power. Data analysis was performed using a t-test of 2 uncorrelated samples. The results revealed that the algebraic finger-based brain gym method has an influence on improving student learning outcomes. This is evidenced by the increase in student learning outcomes after learning with the algebra fingerbased brain gym method obtained an average of 56.25 while the improvement in the learning outcomes of the control class gained an average of 37.50. After testing the hypothesis with t-test 2 uncorrelated samples obtained $t_{\text {count }}=5.7774>t_{\text {table }}=2.0017$. So it can be concluded that the algebraic finger-based brain gym method affects the improvement in student learning outcomes.

Keyword:

Brain Gym, Algebra finger, Learning outcome, Mathematics. 


\section{INTRODUCTION}

Adult education has an important role for every human being. Education is able to deliver the human life of a nation to be more advanced and more prosperous (Komarudin, 2017; Santoso, 2016). The role of education needs to be supported by the quality of education reflected in educational facilities and infrastructure (Dacholfany, 2017; Hasanah et al., 2019), and excellent human resources (HR) (Yunianto et al., 2019; Yusnita et al., 2016). Because the higher the quality of a country's education, the higher the quality of the country's human resources. Because high-quality human resources will improve the welfare of the community (Karyanti \& Komarudin, 2017).

In the education stage, the system sets subjects that must be obtained by students such as subjects that are considered simple to subjects that are considered difficult by most students, namely mathematics (Abdullah \& Suhartini, 2017; Andriani et al., 2019). Mathematics is one of the important subjects to learn because mathematics teaches how to think and find concepts in everyday life (Anggoro et al., 2019; Kusmanto, 2014; Rodiawati \& Komarudin, 2018). According to researchers, a good mathematics teaching and learning process is that educators must be able to create an atmosphere of learning that makes students enthusiastic about the subject matter that is ongoing so that they are able to follow and can understand it. Teacher participation to be more pro-active in the learning process greatly helps the development of children's learning (Haryono, 2009; Rasyid, 2008; Suneki et al., 2012). In learning, the teacher should be able to concretize mathematical objects well so that students can understand the mathematical objects being taught. However, students often assume that mathematics is a difficult subject. So that student in learning less enthusiastic and become bored and not focused on learning.

Mathematics learning in primary schools tends to be dominated by conventional learning which relies more on lecture methods so students become bored and less active in following the learning process (Asani, 2012; Astuti \& Setiawan, 2013; Permana, 2015; Sukmayasa \& Lasmawan, 2013). Therefore we need a fun method that makes children relax in learning (Nuryana \& Purwanto, 2010; Trinova, 2012). One learning method that is fun and able to make students relax is by implementing a brain gym or brain exercise before learning begins (Adriani, 2010; Andre, 2012; Caswati et al., 2017; Widyastuti \& Purwanto, 2009). Brain Gym is an intervention designed by educators and reading specialists, Paul and Gail Dennison, in the 1970s to improve various outcomes including attention, memory, and academic skills (Watson \& Kelso, 2014). Algebra fingers are a basic mathematical calculation method using fingers. This method was invented by Bahruddin $\mathrm{MD}$ and was introduced to the wider community in 2007 and has earned a MURI record in the category of discovery on February 20, 2010, in Semarang. 


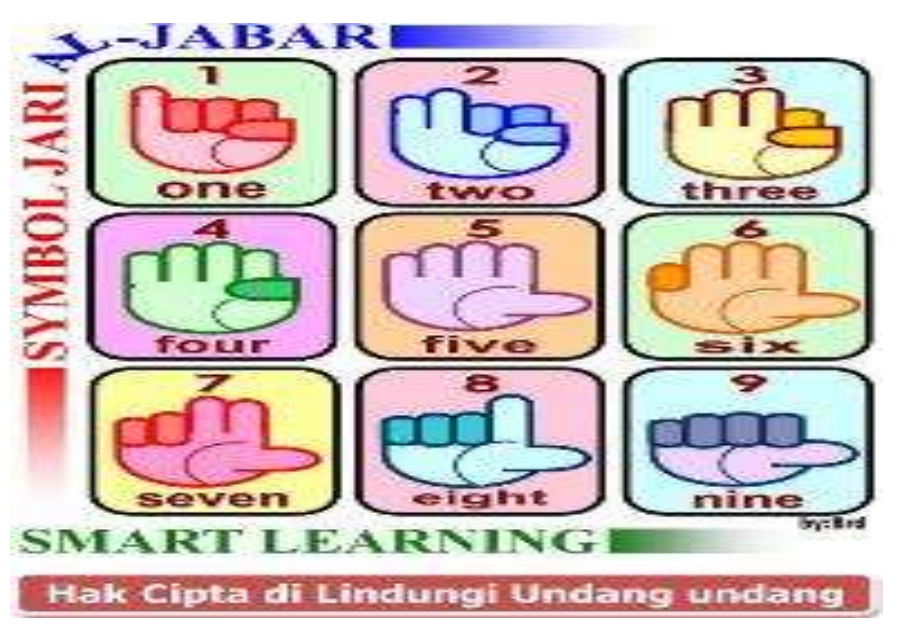

Figure 1. Algebra Finger Symbols

According to Slameto learning outcomes change in behavior that occurs continuously and are not static (Kristin, 2016; Suhendri, 2011). Learning outcomes can be observed including the cognitive domain. The cognitive domain is related to intellectual learning outcomes which consist of six aspects, namely knowledge or memory, understanding, application, analysis, synthesis, and evaluation.

\section{RESEARCH METHODS}

The type of experiment used is a quasi experiment. In this design, the researcher made 2 groups namely the control group and the experimental group. The control group was not given special treatment while the experimental group was treated using the algebraic finger gym-based brain gym method. The independent variable in this study which became the independent variable was the algebraic finger-based brain gym method, the dependent variable in this study which became the dependent variable was an increase in learning outcomes. The population of this study was all students of class VII MTs. AlHidayat Gerning, Tegineneng District, Pesawaran Regency, 2018/2019 Academic Year, which was divided into 4 study groups, namely VII A, VII B, VII C, and VII D, totaling 116 students, all of which were heterogeneous, because they did not use the superior class system. The sample in this study were students of class VII A and VII B MTs. Al-Hidayat Gerning, Tegineneng District, Pesawaran Regency, 2018/2019 Academic Year, amounting to 60 students, in this study class VII A as a control class and class VII B as an experimental class. Sampling was done by cluster random sampling technique.

Data collection techniques used in this study were tests. The test given is in the form of a description test of 6 questions about the addition and subtraction of algebraic material that has been validated. The test is done in 2 stages, the first stage is pretest to find out the students' initial ability and the second stage is posttest to find out the learning outcomes after being given algebraic finger-based brain gym method. The instrument of this study was the student learning outcomes test in the cognitive domain. To get a good instrument, the instrument must first be tested for validity, reliability, difficulty level, and a different power (Binadja et al., 2008; Karim, 2011).

Analysis of the research data was carried out after the data fulfilled the prerequisite tests, namely (1) normality test with the Lilliefors formula; and (2) homogeneity 
test using the Barlett test. Furthermore, the data to be analyzed is obtained from the value of the increase (N-Gain) of learning outcomes from the experimental class and the control class by using t-test 2 samples are not correlated.

\section{RESULTS AND DISCUSSION}

The results of the analysis of the validity of the test instrument learning outcomes test on the addition and subtraction algebra material amounting to 8 items can be seen in Table 1 as follows.

Table 1. Results of Test Validity Tests

\begin{tabular}{lccl}
\hline $\begin{array}{l}\text { No } \\
\text { Item }\end{array}$ & $\mathbf{r}_{\text {table }}$ & $\mathbf{r}_{\text {Count }}$ & Conclusion \\
\hline 1 & 0,361 & 0,382 & Valid \\
\hline 2 & 0,361 & 0,383 & Valid \\
\hline 3 & 0,361 & 0,391 & Valid \\
\hline 4 & 0,361 & 0,384 & Valid \\
\hline 5 & 0,361 & 0,517 & Valid \\
\hline 6 & 0,361 & 0,323 & Not valid \\
\hline 7 & 0,361 & 0,323 & Not valid \\
\hline 8 & 0,361 & 0,453 & Valid \\
\hline
\end{tabular}

Based on Table 1, the results of the validity test of the 8 items tested were tried, there were 2 items that were invalid because the value of $r_{\text {calculated }}<r_{\text {tabel. }}$. The items are numbers 6 and 7, while the items are valid because the value of $r_{\text {count }}>$ $\mathrm{r}_{\text {tabel. }}$ i.e. numbers $1,2,3,4,5$ and 8 .

A difficulty level test is conducted to find out which each item is classified as difficult, moderate, and easy. The difficulty level analysis can be seen in Table 2 as follows.

Table 2. Problem Difficulty Test Results

\begin{tabular}{lll}
\hline $\begin{array}{l}\text { No } \\
\text { Item }\end{array}$ & Difficulty level & Note \\
\hline 1 & 0,250 & Difficult \\
\hline 2 & 0,708 & Easy \\
\hline 3 & 0,544 & Medium \\
\hline 4 & 0,717 & Easy \\
\hline
\end{tabular}

\begin{tabular}{lll}
\hline 5 & 0,608 & Medium \\
\hline 6 & 0,304 & Medium \\
\hline 7 & 0,288 & Difficult \\
\hline 8 & 0,533 & Medium \\
\hline
\end{tabular}

Based on Table 2 above, of the 8 questions that have been tested there are questions with different levels of difficulty, it will take 6 questions with difficult levels of numbers 1 and 7 , moderate levels of difficulty namely numbers $3,5,6$ and 8 , while the difficulty level is easy, namely numbers 2 and 4. Different tests are carried out to examine the extent to which the question instrument can distinguish students who are included in the weak or low category. The results of the analysis of different power items can be seen in Table 3 as follows.

Table 3. Results of Test Points for Different Items

\begin{tabular}{lll}
\hline No Item & $\begin{array}{l}\text { Different } \\
\text { power }\end{array}$ & Note \\
\hline 1 & 0,67 & Good \\
\hline 2 & 0,60 & Good \\
\hline 3 & 0,53 & Good \\
\hline 4 & 0,80 & Good \\
\hline 5 & 0,40 & Enough \\
\hline 6 & 0,10 & Poor \\
\hline 7 & $-0,07$ & Poor \\
\hline 8 & 0,27 & Enough \\
\hline
\end{tabular}

Based on Table 3 above from the 8 items obtained 4 items with good difference because the power difference is between $0.40 \leq \mathrm{DB}<0.70$ which is number $1,2,3$, and 4. Obtained Item 6 and 7 with the difference in power bad, that is, between $1.00 \leq \mathrm{DB}<0.20$ and sufficient power difference with numbers 5 and 8 . Based on the criteria for distinguishing items that will be used to retrieve data, then items number 6 and 7 are not used because the item items have sufficient and ugly distinguishing power. 
After the items were tested for validity, the level of difficulty test, and the difference in power, then the items were tested for reliability. The purpose of reliability testing is to find out the consistency of the instrument as a measurement tool so that the instrument can be trusted to be used as a data collection tool. Based on the results of the reliability test using the Cronbach Alpha formula, the value of $r_{11}=0.650$ is obtained, because $r_{11}>r_{\text {tabel }}$ means that the instrument is reliable with high interpretation. The following are the results of calculating the validity, the level of difficulty test, different power, the instrument is summarized in Table 4 as follows.

Table 4. Recapitulation of Test Results for Test Instruments

\begin{tabular}{lllll}
\hline $\begin{array}{l}\text { No } \\
\text { Item }\end{array}$ & Validity & $\begin{array}{l}\text { Difficulty } \\
\text { level }\end{array}$ & $\begin{array}{l}\text { Different } \\
\text { power }\end{array}$ & Conclusion \\
\hline 1 & Valid & Difficult & Good & Used \\
\hline 2 & Valid & Easy & Good & Used \\
\hline 3 & Valid & Medium & Good & Used \\
\hline 4 & Valid & Easy & Good & Used \\
\hline 5 & Valid & Medium & Enough & Used \\
\hline 6 & Not Valid & Medium & Ugly & Not used \\
\hline 7 & Not Valid & Difficult & Ugly & Not used \\
\hline 8 & Valid & Medium & Enough & Used \\
\hline
\end{tabular}

Based on Table 4 above, the recapitulation of the test results of the test instruments, then from 8 questions tested the researchers took 6 items, namely questions number $1,2,3,4,5$, and 8 . Test the normality of learning outcomes in the material addition and subtraction of algebra. The normality test is carried out in the experimental class and the control class. The results of the analysis of the normality test results of learning outcomes on the material addition and subtraction of algebra learners can be seen in Table 5 as follows.

Table 5. Summary Test for Normality

\begin{tabular}{llcclcll}
\hline No & Class & Pretest & \multicolumn{4}{c}{ Posttest } \\
\cline { 3 - 7 } & & $\mathrm{L}_{\text {count }}$ & $\mathrm{L}_{\text {table }}$ & Conclusion & $\mathrm{L}_{\text {count }}$ & $\mathrm{L}_{\text {table }}$ & Conclusion \\
\hline 1 & Experiment & 0,115 & 0,159 & $\mathrm{H}_{0}$ Accepted & 0,152 & 0,159 & $\mathrm{H}_{0}$ Accepted \\
& & & & & & \\
\hline 2 & Control & 0,152 & 0,159 & $\mathrm{H}_{0}$ Accepted & 0,142 & 0,159 & $\mathrm{H}_{0}$ Accepted
\end{tabular}

Based on Table 5, the calculation results obtained in the experimental class pre-test are $L_{\text {calculate }}=0.115$ while in the control class $L_{\text {calculate }}=0.152$. In the calculation results in the experimental class posttest is $\mathrm{L}_{\text {count }}=0.152$ while in the control class is $\mathrm{L}_{\text {count }}=0.142$ with each $\mathrm{L}_{\text {table }}=0.1590$. The results of normality test calculations in the experimental class and the control class show that Lcalculate $<$ Ltabely which means that $\mathrm{H}_{0}$ is accepted. So, it can be concluded that the experimental class and 
the control class are samples from populations that are normally distributed.

The next test is the homogeneity test. The results of the homogeneity test data analysis of the experimental class and control class students are presented in Table 6 as follows.

Tabel6. Rekapitulasi Uji Homogenitas

\begin{tabular}{llrcl}
\hline No. & Group & $\chi_{\text {count }}^{\mathbf{2}}$ & $\boldsymbol{\chi}_{\text {table }}^{\mathbf{2}}$ & Conclusion \\
\hline 1 & Pretest & 1,184249 & 3,841 & Homogen \\
\hline 2 & Posttest & 0,610439 & 3,841 & Homogen \\
\hline
\end{tabular}

Based on Table 6 above, it is obtained that the results of the pre-test homogeneity test data analysis are obtained $\chi_{\text {hitung }}^{2}=$ 1,184 with $\chi_{\text {tabel }}^{2}=3,841$ posttest was obtained $\chi_{\text {hitung }}^{2}=0,610$ with $\chi_{\text {tabel }}^{2}=$ 3,841 . The results of these calculations show that $\chi_{\text {hitung }}^{2} \leq \chi_{\text {tabel }}^{2}$ so, H0 be accepted, meaning that both samples are from the same population (homogeneous).

The first hypothesis in this study was tested by t-test 2 samples did not correlate and the results are presented in Table 7 as follows.

Table 7. Recapitulation of Hypothesis Test Results

\begin{tabular}{llrrrr}
\hline No & Kelompok & $\mathrm{N}$ & $\mathbf{t}_{\text {count }}$ & $\mathbf{t}_{\text {table }}$ & Conclusion \\
\hline 1 & Experiment & 30 & \multirow{2}{*}{5,777498} & 2,00172 & \multirow{2}{*}{ H0 Rejected } \\
2 & Control & 30 & & & \\
\hline
\end{tabular}

Based on Table 7 about the recapitulation of the above hypothesis test results can be concluded as follows: tcount $=5.7774$ and ttable $=2.0017$ The calculation results have shown that tcount $>$ ttable this means that the value of tcount obtained is greater than ttable. The overall calculation results show that the two treatments clearly differ (significantly) then $\mathrm{H}_{-} 0$ is rejected. This data shows that there is an influence of algebraic finger-based brain gym methods. This is consistent with the results of other studies that the brain gym method has a significant difference (Sukri \& Purwanti, 2016).

The N-Gain Test was carried out in the experimental class and the control class. The results of the analysis of N-Gain test data for the experimental class and control class can be seen in Appendix 12. As for the highest N-Gain of the experimental class is 15.59 , while the control class is 5.470 .

The learning outcomes of students who use the Algebra-based gym methodology are better than using conventional learning methods. Because students who obtain the algebraic finger-based brain gym method feel relaxed by learning in collaboration, discussing groups, and presenting the results of group discussions (Saputra \& Hakim, 2017). In addition, students are more active and creative so that they are able to solve problems that are given well and not a few of the students feel challenged to count many questions given by practicing algebraic fingers with their group of friends..

Besides the algebraic finger gym brain method also trains the skills of the hand where it has to do with learning outcomes 
in the psychomotor domain. The algebra finger-based brain gym method is also a practical and inexpensive method so that it can improve learning outcomes and can be done anywhere and anytime so that this method can be used to improve the learning process (Ginting, 2019).

When this learning takes place students are seen to find information from each other and learn from other students, comparing each other's ideas or ideas from other groups who present their group's work. Whereas in the control class that uses conventional learning methods students look less active in participating in learning, students are given an explanation of the material, take notes, and are given work to do so that learning seems monotonous, in this case, learning is centered on educators. Thus students are less active in expressing ideas and less developing their abilities. By implementing an algebraic finger-based brain gym the cognitive abilities of

\section{REFERENCES}

Abdullah, A. A. \& Suhartini, S. (2017). Meningkatkan Kemampuan Berpikir Kritis Melalui Pembelajaran Statistika Berbasis Pendidikan Politik Di Lingkungan Sekolah. Jurnal Gantang, 2(1), 1-9.

Adriani, E. (2010). Efektivitas Brain Gym Dalam Meningkatkan Kecakapan Matematika Pada Pokok Bahasan Operasi Hitung Bilangan. Universitas Muhammadiyah Surakarta.

Andre, Y. (2012). Efektivitas Penggunaan Metode Brain Gym terhadap Minat Belajar IPA Siswa Kelas V SD Negeri Kalibeji Kecamatan Tuntang Kabupaten Semarang Semester II Tahun Pelajaran 2011/2012. Program Studi Pendidikan Guru Sekolah Dasar FKIP-UKSW.

Andriani, S., Suyitno, H., \& Junaidi, I. (2019). The Application of Differential Equation of Verhulst Population Model on Estimation students can be assessed optimally (Mariyani, 2019).

The results obtained by researchers have relevance to previous research results that there is a significant influence of brain gym on students' mathematics learning outcomes (Fajriati et al., 2017), in addition to that, the method of brain gym can be used in formal and informal assessments (Nugroho \& Hardjajani, 2009). Therefore, this method can be used as an alternative in learning in class.

\section{CONCLUSION}

Students with learning treatment using algebraic finger-based brain gym methods have improved learning outcomes better than students with learning treatment using conventional learning methods with the results of hypothesis testing with the t-test statistical test obtainedt $\mathrm{t}_{\text {hitung }}=$ $5,7774>t_{\text {tabel }}=2,0017$.

of Bandar Lampung Population. Journal of Physics: Conference Series, 1155, 012017.

Anggoro, B. S., Efendi, H., \& Suherman, S. (2019). The Impact Of Ethnomathematics-Based Probing-Prompting Learning Method On Class IX SMP Negeri 2 Way Tenong Studentsmathematical Communication Skills Year 2016/2017. Asian Journal of Current Research, 1-8.

Asani, D. (2012). Efektifitas Strategi Pembelajaran MURDER Terhadap Partisipasi Dan Kemampuan Berpikir Analitis Siswa SMA Negeri 1 Gombong Pada Mata Pelajaran Biologi. Fakultas Keguruan dan Ilmu Pendidikan Universitas Sebelas Maret (UNS): Surakarta. biologi. fkip. uns. ac. id/wpcontent/uploads/2012/.../SKRIPSIDISKA.pdf.

Astuti, Y., \& Setiawan, B. (2013). Pengembangan lembar kerja siswa (LKS) berbasis 
pendekatan inkuiri terbimbing dalam pembelajaran kooperatif pada materi kalor. Jurnal Pendidikan IPA Indonesia, 2(1).

Binadja, A., Wardani, S., \& Nugroho, S. (2008). Keberkesanan pembelajaran kimia materi ikatan kimia bervisi SETS pada hasil belajar siswa. Jurnal Inovasi Pendidikan Kimia, 2(2).

Caswati, C., Sugihartono, S., \& Sutjiati, N. (2017). Pengaruh Brain Gym Terhadap Minat Dan Hasil Belajar Dalam Pembelajaran Bahasa Jepang. EDUJAPAN, 1(1), 94103.

Dacholfany, M. I. (2017). Inisiasi Strategi Manajemen Lembaga Pendidikan Islam Dalam Meningkatkan Mutu Sumber Daya Manusia Islami di Indonesia Dalam Menghadapi Era Globalisasi. At-Tajdid: Jurnal Pendidikan dan Pemikiran Islam, 1(01).

Fajriati, I. S., Safei, S., \& Saprin, S. (2017). Pengaruh Penerapan Metode Pembelajaran Brain Based Learning Berbantuan Brain Gym Terhadap Hasil Belajar Peserta Didik. JurnalBiotek, 5(1), 1-10.

Ginting, S. S. B. (2019). Peningkatan Kemampuan Berpikir Kreatif Matematis Dan Kemandirian Belajar Siswa SMP ArRahman Medan Melalui Pembelajaran Open-Ended Berbasis Brain-Gym. AXIOM: Jurnal Pendidikan dan Matematika, $8(1)$.

Haryono, A. (2009). Authentic assessment dan pembelajaran inovatif dalam pengembangan kemampuan siswa. Jurnal Pendidikan Ekonomi, 2(1).

Hasanah, U. N., Thahir, A., Komaruddin, K. \& Rahmahwaty, R. (2019). MURDER Learning and Self Efficacy Models: Impact on Mathematical Reflective Thingking Ability. Journal for the Education of Gifted Young Scientists, 7(4), 1123-1135.

Karim, A. (2011). Penerapan metode penemuan terbimbing dalam pembelajaran matematika untuk meningkatkan pemahaman konsep dan kemampuan berpikir kritis siswa sekolah dasar. Jurnal Pendidikan, 1(1), 21-32.

Karyanti, K., \& Komarudin, K. (2017). Pengaruh Model Pembelajaran Kumon Terhadap Pemahaman Matematis Ditinjau Dari Gaya Kognitif Peserta Didik Pada Mata Pelajaran Matematika Kelas VIII SMP Negeri Satu Atap 4 Pesawaran. Prosiding Seminar Nasional Matematika dan Pendidikan Matematika, 1, 89-94.

Komarudin, K. (2017). Analisis kesalahan siswa dalam pemecahan masalah matematika pada materi peluang berdasarkan high order thinking dan pemberian scaffolding. Jurnal Darussalam: Jurnal Pendidikan, Komunikasi dan Pemikiran Hukum Islam, 8(1), 202-217.

Kristin, F. (2016). Efektivitas Model Pembelajaran Kooperatif Tipe STAD Ditinjau Dari Hasil Belajar IPS Siswa Kelas 4 SD. Scholaria: Jurnal Pendidikan dan Kebudayaan, 6(2), 74-79.

Kusmanto, H. (2014). Pengaruh Pemahaman Matematika Terhadap Kemampuan Koneksi Matematika Siswa Kelas Vii Semester Genap SMP Negeri 2 Kasokandel Kabupaten Majalengka. Eduma: Mathematics Education Learning and Teaching, 3(2).

Mariyani, A. (2019). Penyuluhan dan Pelatihan Peningkatan memori siswa SD melalui Braingym bagi Guru Sekolah Dasar. JPMB: Jurnal Pemberdayaan Masyarakat Berkarakter, 2(2), 199-206.

Nugroho, I. S., \& Hardjajani, T. (2009). Engaruh Pelatihan Brain Gym Terhadap Perkembangan Kemampuan Literacy Pada Anak Kelas Satu Sekolah Dasar. WACANA, 1(2).

Nuryana, A., \& Purwanto, S. (2010). Efektivitas brain gym dalam meningkatkan konsentrasi belajar pada anak. Indigenous: Jurnal Ilmiah Psikologi, 12(1).

Permana, E. P. (2015). Penerapan Metode Problem Solving Dengan Media Gambar Seri Untuk Meningkatkan Hasil Belajar IPS 
Kelas IV Sekolah Dasar. Jurnal Pendidikan Dasar Nusantara, 1(1).

Rasyid, M. R. (2008). Optimalisasi Peran Guru dalam Proses Transformasi Pengetahuan dengan Menggunakan Media Pembelajaran. Lentera Pendidikan: Jurnal Imu Tarbiyah dan Keguruan, 11(1), 55-68.

Rodiawati, H., \& Komarudin, K. (2018). Pengembangan e-learning melalui modul interaktif berbasis learning content development system. Jurnal Tatsqif, 16(2), 172-185.

Santoso, H. (2016). Pembelajaran Di Sekolah Sebagai Wahana Pengembangan Karakter Perserta Didik. Jurnal Lentera Pendidikan Pusat Penelition LPPM UM Metro, 1(2), 197-203.

Saputra, B. C., \& Hakim, A. R. (2017). Perbandingan Hasil Belajar Matematika dengan Structured Dyadic Method dan Brain Gym Method. JKPM (Jurnal Kajian Pendidikan Matematika), 2(2), 183-192.

Suhendri, H. (2011). Pengaruh kecerdasan matematis-logis dan kemandirian belajar terhadap hasil belajar matematika. Formatif: Jurnal Ilmiah Pendidikan MIPA, 1(1).

Sukmayasa, I. M. H., \& Lasmawan, I. W. (2013). Pengaruh Model Pembelajaran Kooperatif Tipe NHT Berbantuan Senam Otak terhadap Keaktifan dan Prestasi Belajar Matematika. PENDASI Jurnal Pendidikan Dasar Indonesia, 3(1).
Sukri, A., \& Purwanti, E. (2016). Meningkatkan hasil belajar siswa melalui brain gym. Jurnal Edukasi Matematika dan Sains, 1(1), 50-57.

Suneki, S., Ambarini, R., \& Destriani, D. (2012). Brain-gym (Senam Otak) Untuk Mengatasi Problem Belajar Anak. EDimas: Jurnal Pengabdian kepada Masyarakat, 3(1), 7-14.

Trinova, Z. (2012). Hakikat Belajar dan Bermain Menyenangkan bagi Peserta Didik. Al-Ta Lim Journal, 19(3), 209-215.

Watson, A., \& Kelso, G. L. (2014). The Effect of Brain Gym ${ }^{R}$ on Academic Engagement for Children with Developmental Disabilities. International Journal of Special Education, 29(2), 75-83.

Widyastuti, R., \& Purwanto, S. (2009). Efektivitas Brain Gym Dalam Menurunkan Stres PadaAnak.

Yunianto, T., Negara, H. S., \& Suherman, S. (2019). Flip Builder. Pengembangannya Pada Media Pembelajaran Matematika. TERAMPII: Jurnal Pendidikan dan Pembelajaran Dasar, 6(2), 115-127.

Yusnita, I, Maskur, R., \& Suherman, S. (2016). Modifikasi model pembelajaran Gerlach dan Ely melalui integrasi nilai-nilai keislaman sebagai upaya meningkatkan kemampuan representasi matematis. AlJabar: Jurnal Pendidikan Matematika, 7(1), 29-38. 